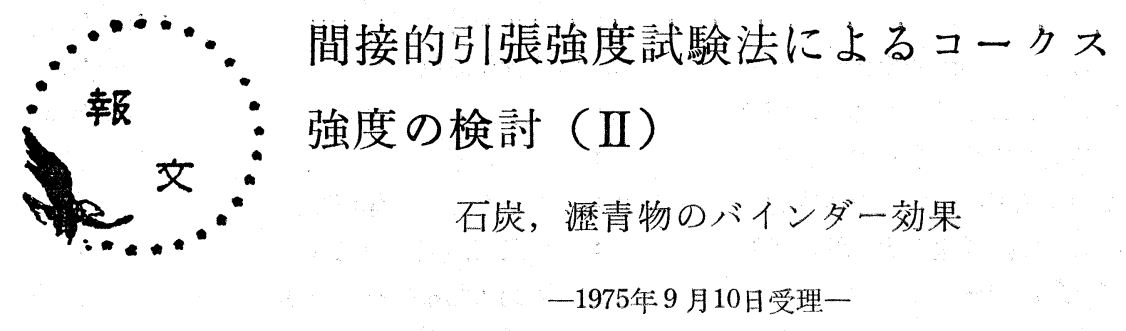

1. 緒 言

成型コーフスに打いて軟化溶融性の劣る粒子を相互 に結合するのは軟化溶融性の優れた石炭, 瀝青物など の炭素質,すなわちバインダーである。これらの炭素 質が不活性物粒子を相互に結合する際の結合力の大き さを知ることは成型コークス用原料炭の配合組成や各 原料炭の役割を理解する上に必要である。

前報 ${ }^{1)}$ て間接的引張強度試駼法 (I. T. T. 法) を室 炉コークスに適用し, 粒子間結合力を表示する比較的 優れた方法であることを述べた。本報は不活性物に各 種のバインダー（石炭類拈よび瀝青物類）を添加して 不活性物粒子間の結合力の大きさを I. T. T. 法で測定 することによってバインダーの特性と結合力との関係 を把握することを目的としている。

\section{2. 石炭類による不活性物粒子間結合効果}

成型コークス用原料炭として強粘結炭や高流動性炭 などの軟化溶融性の優孔た石炭種も少量ながら用いら れる ${ }^{2 \sim 44}$ 。これらの石炭種は乾留過程で Thermobitu-

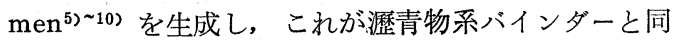
様に不活性物粒子間を相互に接着結合する効果をるっ ているるのと考光られる。また, Thermobitumen の

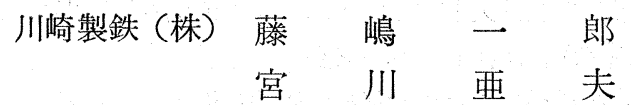

性状は石炭化度, すなわち活性質のタイプによって異 なると予想される。そこで, 﨡質の夕イプ (平均反 射率) の異なる各種の石炭と不活性物との混合物を乾 留し, 生成したコークスの引張強度から石炭種による 不活性物粒子間結合力の相異を知ることを試みた。

2.1 供試試料

Thermobitumen を全く生成しない非粘結性不活性 物としてコークスブリーズおよび無煙炭であるホンゲ イ炭を用いた。石炭は活性質の平均反射率0.78 1.7. \%の範囲から選び，その分析值を Table 1 に示した。 I. T. T. 法を適用する場合コークスの均質性が要求さ れること，拉よび不活性物粒子自体の破断を防ぐこと を考慮してこれらの試料は200メッシュよりも細かく 粉砕して用いた。

\section{2 引張強度試験用試料の作成}

Table 1 の試料炭と不活性物を任意の 割合に充分混 合し, 内径 $20 \mathrm{~mm} \phi$ のステンレス製円筒金型に装入 した。装入量は高さ $30 \mathrm{~mm} て ゙ 一$ 定とし, 試料層の上部 に高さ $30 \mathrm{~mm}$ のレンガ拉よび高さ $25 \mathrm{~mm}$ のステンレス 製重錘をのせた。この金型を電気炉で室温から $800^{\circ} \mathrm{C}$ まで $3.3^{\circ} \mathrm{C} / \mathrm{min}$ の界温速度で加熱し, $800^{\circ} \mathrm{C}$ に 時

Table 1 Analysis of sample coals

\begin{tabular}{lcccccc}
\multicolumn{1}{c}{ Coal } & $\begin{array}{c}\text { Vitrinite } \\
(\text { vol. } \%)\end{array}$ & $\begin{array}{c}\text { Exinite } \\
(\text { vol. } \%)\end{array}$ & $\begin{array}{c}\text { Total } \\
\text { Reactive } \\
(\text { vol. } \%)\end{array}$ & $\begin{array}{c}\overline{\mathrm{R}} \max \\
(\%)\end{array}$ & $\begin{array}{c}\text { V.M. } \\
(\% \text {-d. a.f. })\end{array}$ & $\begin{array}{c}\text { Ash } \\
(\% \text { dry })\end{array}$ \\
Yutoku & 86.7 & 5.6 & 92.3 & 0.89 & 41.1 & 6.3 \\
Newdell & 70.4 & 7.6 & 78.0 & 0.78 & 40.2 & 9.6 \\
Black water & 52.6 & 3.2 & 55.8 & 1.09 & 27.5 & 8.6 \\
Rowland & 77.4 & 4.2 & 81.6 & 1.18 & 28.7 & 5.7 \\
K-10 & 73.3 & 2.4 & 75.7 & 1.28 & 27.0 & 7.4 \\
Port Kembla & 46.9 & - & 46.9 & 1.33 & 22.5 & 10.9 \\
Balmer & 62.2 & - & 62.2 & 1.33 & 22.8 & 10.8 \\
Beatrice & 86.2 & - & 86.2 & 1.70 & 17.4 & 4.0
\end{tabular}


間保った後に炉から取り出した。コークスブリーズと 試料炭の配合割合が適当な場合には均質でち密な円筒 型コークス塊が得られた。この塊の形状を計測した 後, 塊を $3 \sim 4$ 個の薄片飞切り分け, 薄片の両側面を 平滑にみがいて直径約 $19 \mathrm{~mm} \phi$, 厚さ $5 \mathrm{~mm}$ の引張強 度試験片に仕上げた。試料片は一つの配合率について 約 40 本作成した。I. T. T. 法に上る引張試験法の詳細 は前報1のと和りである。測定された引張強度はバラ
ツキはあるが，ほぼ一定していたので算術平均をもっ て平均引張強度とした。

\section{3 結果扔よび考察}

Fig. 1 亿引張強度試験結果を示した。図から各炭種 とも不活性物の配合量の変化に伴って引張強度に極大 值が存在していること，この極大值に和ける不活性物 配合量は炭種によって異なっていること，不活性物の 種類によらず, 引張強度最大点に和ける不活性物の唒己
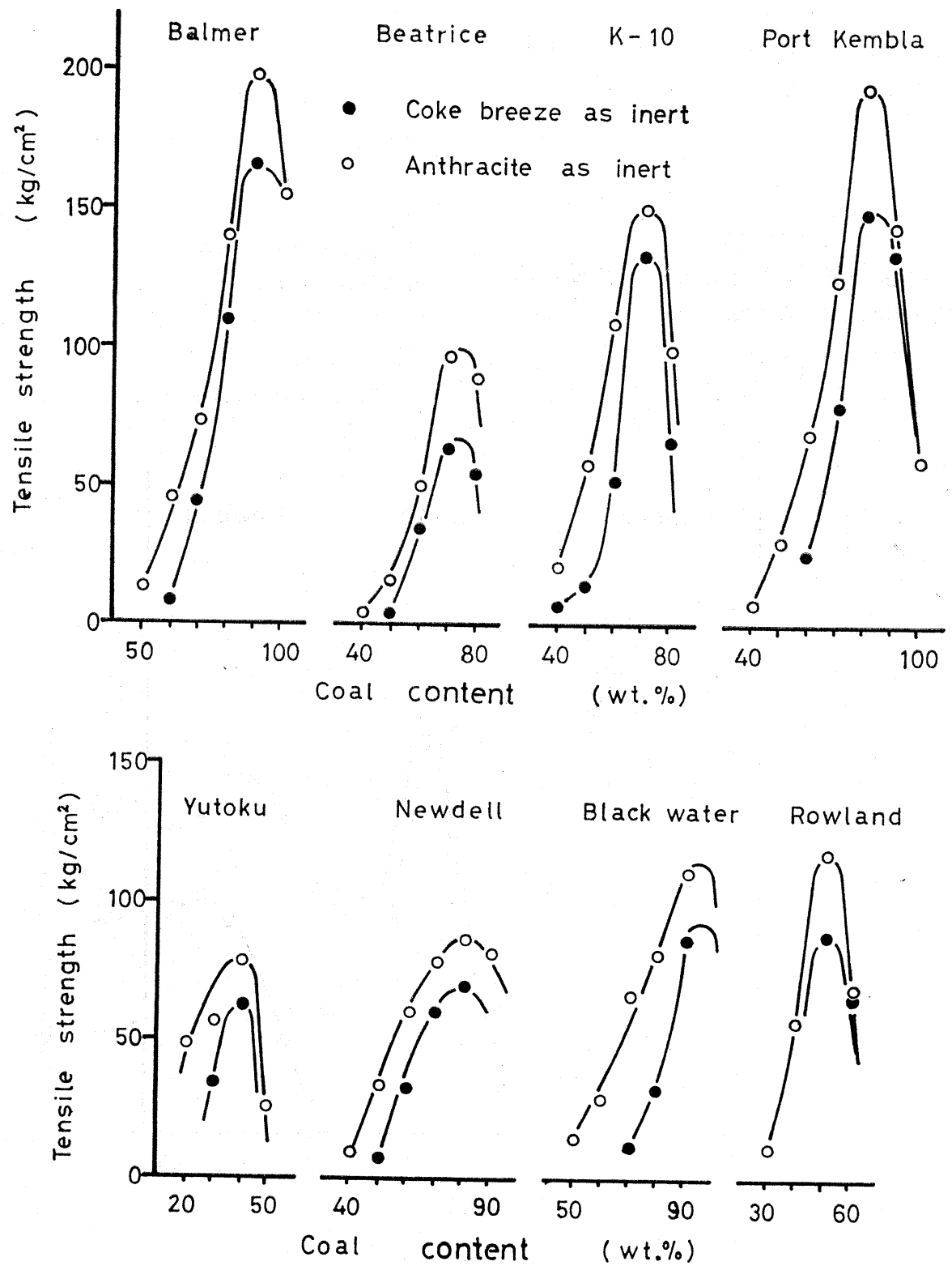

Fig. 1 Efect of coal addition on the tensile strength 
合重量が一致していることがわかる。これらの諸点に ついて以下に考察する。

\subsection{1 コークスの気孔壁強度}

この実験で作成したコークスは室炉コークスのよう な大きな亀裂や気孔は存在しなかったが，微小な気孔 は無数に存在した。そのため I. T. T. 法で算出した引 張強度は気孔部も含めた単位面積当りの強度である。 バインダーの炭化物としての炭素基質部のみに基づく 不活性物粒子間の引張強度を求めるには気孔・空隙に よる面積を補正する必要がある。引張試験片中の気孔 の分布が均一であると仮定し，その気孔率を $\alpha$, I. T. T. 法による引張強度を $F$ とすると (1) 式が成立す る。

$$
f=\frac{f}{1-\alpha}
$$

ただし， $f$ : 炭素基質部のみによる引張強度

ここで, 引張試験片の見掛比重を $d_{A}$ 真比重を $d_{R}$ とすると気孔率 $\alpha$ は (2) 式で表わされる。

$$
\alpha=1-\frac{d_{A}}{d_{R}}
$$

（2）式を（1）式に代入して

$$
f=\frac{F}{1-\alpha}=d_{R} \cdot \frac{F}{d_{A}}
$$

引張試験片の真比重 $d_{R}$ は乾留温度が充分高く, 乾 留時間が長ければ原料炭種のいかんを問わずコークス ブリーズの真比重 1.94 (実測值)に近づくはずであ る。すなわち， $d_{R}$ は定数とみなせるので相対的には $\mathrm{F} / d_{A}$ が求まれば充分である（実際には原料炭種によ って $d_{R}$ は若干異なったが，考察に影響を与えるほど の相異でなかったので無視した)。そこで， $\mathrm{F} / d_{A}$ を接 着強度 (Agglutination strength) と定義し，接着強 度と石炭添加量の関係の一例を Fig. 2 に示した。本節 の実験に用いた不活性物は引張試験によってそれ自体 が破断しないように微粉砕してあるので，(3) 式の $f$ あるいは $\mathrm{F} / d_{A}$ はバインダーによって形成されたコ ークス気孔壁の強度を表わしていることになる。

仮に不活性物がバインダーを希釈する効果のみを果 たすならば不活性物の配合量を増加させるに従って $\mathrm{F} / d_{A}$ は単調減少するはずである。しかし，Fig. 2 に よると引張強度と同様に極大強度が存在して扣り, バ

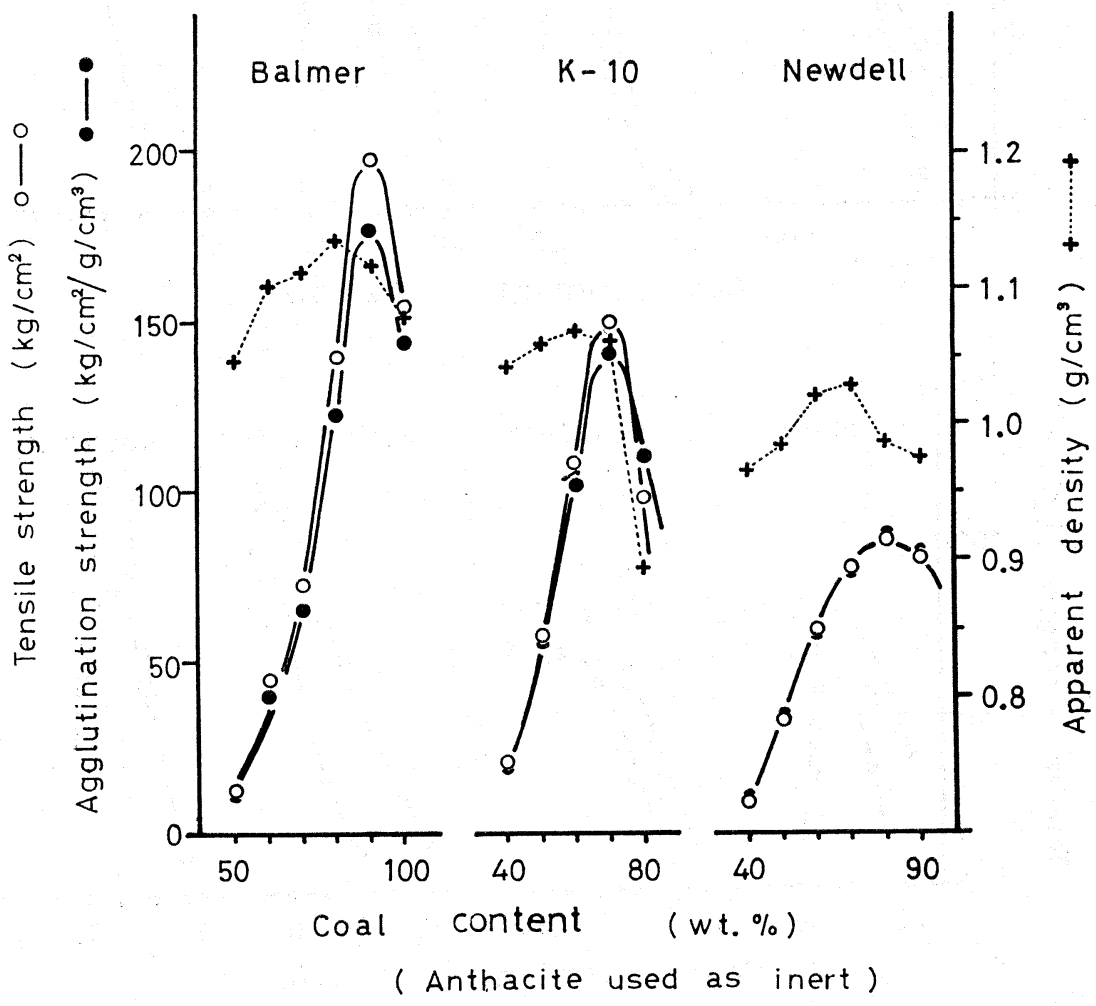

Fig. 2 Relation between agglutination strength and coal addition 
インダーと不活性物の相互作用によって気孔壁強度が 変化することを示している。これは乾留過程で石炭か ら生成したThermobitumen が不活性物粒子に吸着固 化され ${ }^{11)}$, Thermobitumenの粘度が適度に調整され るとコークス気孔壁を厚くし，壁構造を強化する ${ }^{12) 131}$ ためと考觉られる。

2.3.2 活性質のタイプと最大引張強度の関係

Fig. 1 から石炭種によって最大引張強度が異なって いることがわかる。この点を明確にするため, Fig. 1 を各石炭の活性值の平均反射率と最大引張強度の関係 になおしたものが Fig. 3 である。平均反射率 1.3〜

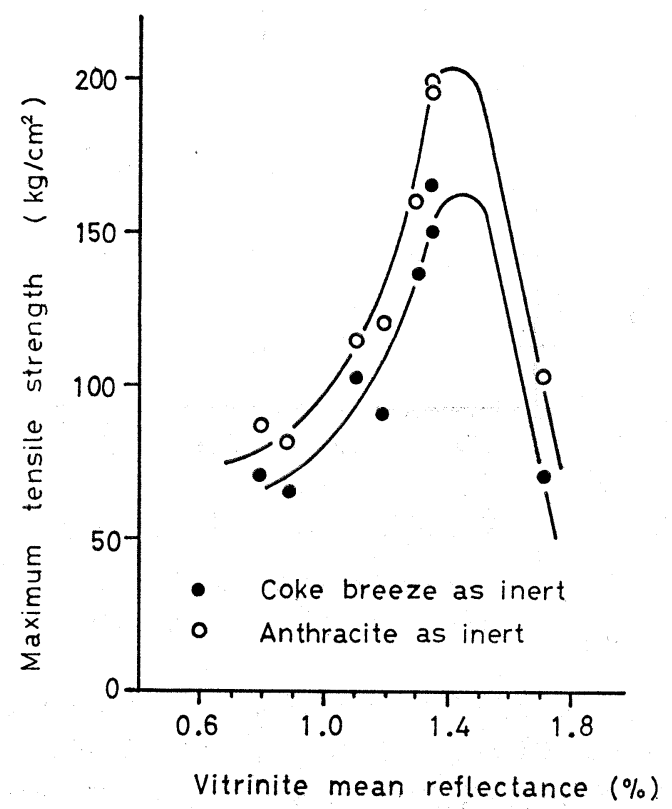

Fig. 3 Efect of vitrinite type on the maximum tensile strength of coke

$1.4 \%$ 付近の活性質が最大引張強度を最も高める作用 があり, 平均反射率によって最大引張強度が規則的に 変化していることがわかる。

\subsection{3 不活性物の種類と引張強度}

Fig. 1 亿よると不活性物はコークスブリーズでも無 煙炭でも引張強度を最大にする不活性物の重量はほぼ 等しく, 不活性物重量の増加々引張強度の変化の関係 は類似している。この理由は現在のところよくわから ない。不活性物として無煙炭を用いた場合の方がコー クスブリーズを用いた場合よりも引張強度が高かった のは両者の細孔構造の相異により, コークスブリース の方が多量の Thermobitumen を細孔の穴埋めに消

費1114)するためであろう。

2.3.4 不活性物の最適配合量と活性質のタイプの 関係

200 メッシュよりも細かく粉䃅した不活性物は石炭 組織成分上不活性質の一種とみなしてよかろう。した がって，石炭に微粉砕した不活性物を配合することは 石炭中の不活性質の量を人為的に変化させることを意 味する。ここで, 不活性物配合炭中の活性質の量を試 算してみる。 $n$ 種の石炭を配合したときの活性質の量 が $v_{B}($ vol. $\%), i$ 番目の石炭の配合量を $m_{i}$, 真比重 を $d_{i}$, 体積を $V_{i}$, 活性質の量を $T R_{i}(\operatorname{vol} . \%)$ とし, 配合炭の全実質值を $V_{B}$ とする。このとき, 次の (4) （6）式が成立する。

$$
\begin{gathered}
V_{i}=\frac{m_{i}}{d_{i}} \\
V_{B}=\sum V_{i} \\
v_{B}=\frac{\sum\left(V_{i} \cdot T R_{i}\right)}{V_{B}}
\end{gathered}
$$

(4)，(5) 式を（6）式に代入して，

$$
v_{B}=\frac{\sum\left(\frac{m_{i}}{d_{i}} \cdot T R_{i}\right.}{\sum \frac{m_{i}}{d_{i}}}
$$

が成立する。コークスブリーズや無煙炭を不活性質の みから成る石炭 $\left(T R_{i}=0\right)$ とみなせば，(7) 式から不 活性配合炭の活性質の量を求めることができる。(7)式 を適用するためには各試料炭の比重を求めて和く必要 がある。Table 2 に試料炭の真比重の実測結果を示し た。(7) 式によって Fig. 1 の引張強度最大のときの活 性質の量を容量百分率 (vol. \%) で求め, これを活性

\section{Table 2 Specific gravity of sample coals and inerts}

inerts

Coke Breeze

Anthracite

Coals

$\begin{array}{ll}\text { Balmer } & 1.36 \\ \text { Beatrice } & 1.31 \\ \text { Black water } & 1.35 \\ \text { Rowland } & 1.31 \\ \text { Yutoku } & 1.26 \\ \text { Newdell } & 1.32 \\ \text { K-10 } & 1.32 \\ \text { Port Kembla } & 1.39\end{array}$

Specific gravity

1. 94

1. 35

1. 36

1. 31

1.35

1. 31

1. 26

1. 32

1.32

39 


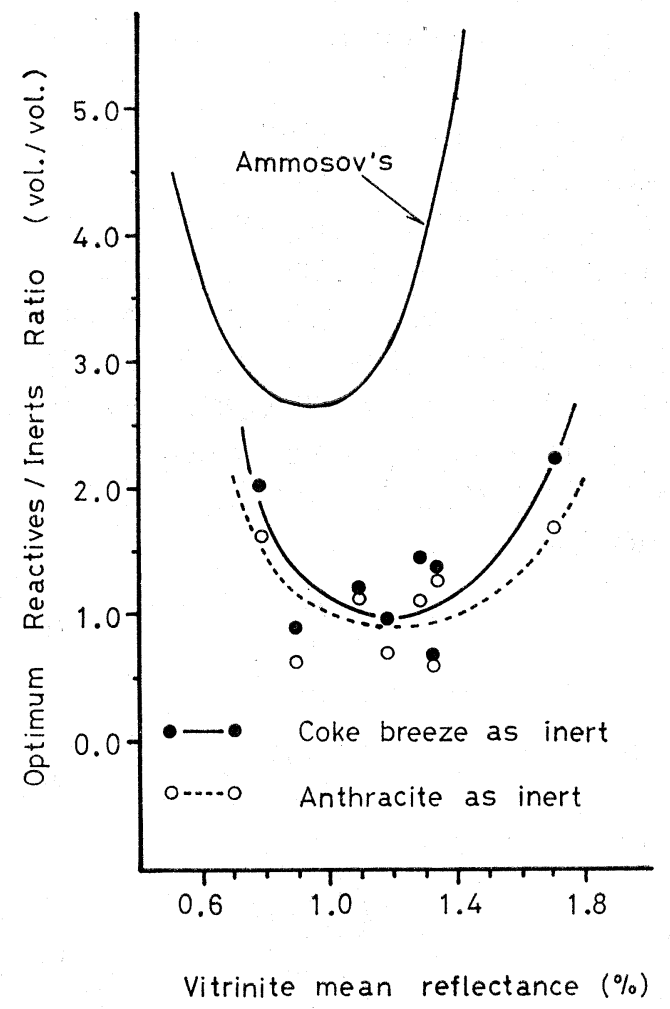

Fig. 4 Optimum inert ratio curve

質の平均反射率之関係付けて Fig. 4 亿示した。な掊 Fig. 4 の縦軸は活性質の量そのものではなく，活性質 の量/不活性質の量 (vol. / / vol.) をもって表示した。 これがいわゆる最適不活性質量曲線 (Optimum Inert Ratio Curve, O.I.R. 曲線) である。図中には, Ammosov $~^{15)}$ の求めた O.I.R. 曲線も示した。筆者ら の求めた曲線と Ammosov らの曲線はかなりずれて いるが, これは試料炭種, 乾留条件, 強度測定法など が両者で異なっていたためであろら。しかし，一定の 平均反射率のところで, 不活性質の配合量が極大にな る傾向は両者で一致している。筆者らの実験では図に 見られるごとく平均反射率 $1.2 \sim 1.4 \%$ 付近の活性質 が不活性物を最も多量に配合できることが示された。 不活性物としてコークスブリーズを用いた場合と無煙 炭を用いた場合とで比較すると, 無煙炭を用いた場合 の方が不活性物の配合性が優れているように見光る。 これは Fig. 1 から明らかなように, 同一の活性質に 対しては不活性物の最適配合量は不活性質の種類にか かわらず同一重量であるが，O.I. R. 曲線は不活性物 の最適配合量を重量百分率ではなく容量百分率で表
わしているため比重の低い無煙炭の方が体積上多量に 配合できるからである。すなわち, 不活性物の最適配 合量を容量百分率で表 示した場合にはその比重に充 分留意する必要がめる。因みに本節の実験に用いた試 料炭を塩化亜鉛比重液で活性質部分と不活性質部分に 分離（活性質，不活性質各々 $90 \%$ 以上飞濃縮）し, それぞれの部分について比重を測定した結果を Fig. 5 に示した。活性質，不活性質共石炭化度が高くなるに

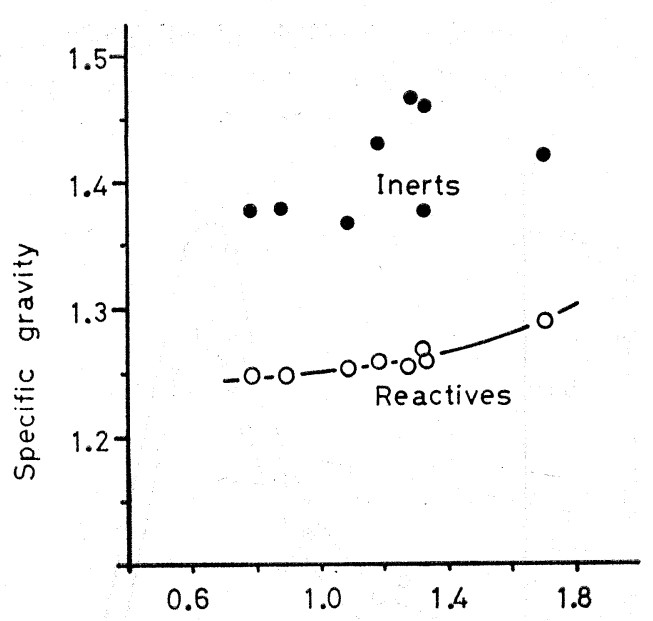

Vitrinite mean reflectance $(\%)$

Fig. 5 Relation between vitrinite mean reflectance and specific gravity

つれて比重が高くなるが, 不活性質ではバラッキが大 きいことがわかる。これは, 不活性質の比重が単に石 炭化度のみでは規定されず，炭種によって固有の差を 有することを示している。これまで報告されている不 活性物の最適配合量 ${ }^{16)}$ 21) が研究者によってかなり異 なっているのは炭種によって活性質の比重が大幅に異 なるにもかかわらず組織分析によって容量百分率で 求めた O.I.R. 曲線を利用しているためであろう。

2.4 を め

本節での結果をまとめると，

1. 最適不活性物 配合量は平均反射率 $1.2 \sim 1.3 \%$ 付近の活性質で最も多く, 平均反射率がこの付近から ずれるに従って少なくなる。

2. 不活性物の最適配合量は不活性物の量を重量 百分率で表わした場 合には不活性物の種類によらず, 活性質の平均反射率によって一定している。

3. 不活性物を最適配合した場合の引張強度は平均 反射率 $1.3 \sim 1.4 \%$ の活性質で最も高い。 
したがって，石炭類をバインダーとして用いる場合 には，平均反射率 $1.3 \sim 1.4 \%$ 付近の活性質を有する 炭種（準強粘結炭～强粘結炭）であって不活性質の含 有量の少ないものがよいことになる。このような炭種 は不活性物を多量に配合でき, かつ最大引張強度も高 いからである。一方, 高流動性弱粘結炭である夕特炭 は活性質の平均反射率約 $0.9 \%$ で最大引張強度はさほ ぞ高くない (Fig. 3 参照) が， 不活性質をほとんど含 まないため不活性物配合性は他の炭種に比較して著し く高く, 成型コークス用のバインダーとして有効であ ろう。

\section{3. 厡青物による不活性物粒子間結合効果}

バインダーとして最も普遍的な瀝青物について不活
性物粒子間結合効果を検討した。不活性物としてはコ ークスブリーズのみを用いた。

\section{1 供試試料}

瀝青物は主にその重質化の程度に着目して比較的軽 質なストレートアスファルトから重質な石炭ビッチの 範囲から選択した。アスファルトとしては減圧残油の ストレートアスファルトを用いた。アスファルトより も若干重質な瀝青物として，このアスファルトからア スファルテンを分離した。さらに重質な瀝青物として アスファルトを無触媒・不活性気流下で 5 時間 $380^{\circ} \mathrm{C}$ で加熱処理した改質アスファルトを用いた。最も重質 な瀝青物として川鉄化学（株）製の石炭ビッチを用い た。

Table 3 Fractionation of bitumen (wt $\%)$

$\begin{array}{lcccc} & \text { Asphalt } & \text { Asphaltene } & \begin{array}{c}\text { Treated } \\ \text { asphalt }\end{array} & \begin{array}{c}\text { Coal tar } \\ \text { pitch }\end{array} \\ n \text {-Pentane insol. } & 21.1 & 100 & 61.3 & 93.0 \\ \text { Benzene insol. } & - & - & 19.7 & 39.8 \\ \text { Chloroform insol. } & - & - & 14.7 & 33.0\end{array}$

これらの瀝青物をコークスブリーズと任意の割合に 図から重質化した䇛青物ほど同一配合率に和ける引張 強度が高いこと, 瀝青物の種類によらず引張強度が最 大になるときの歴青物の 重量割合は 25～28wt.\%で 一定していることがわかる。以下にこれらの諸点につ いて考察する。

3.2 .1 瀝青物の重質化の程度と引張強度の関係 同一配合量では重質化した歴青物ほど引張強度が高 いことから, 瀝青物の重質化の程度と引張強度の間に 密接な関係のあることが予想される。瀝青物の重質化 の程度を表示する指標には溶媒不溶分量, 比重, H/C (原子数比), 芳香族性指数 $\left(\mathrm{f}_{a}\right)^{28)}$, 量, コンラドソ ンカーボン量などがある。試料として用いた歴青物に ついてこれらの各指標と引張強度の関係を調べた。そ の結果, 比重, $\mathrm{H} / \mathrm{C}$ (原子数比), $\mathrm{f}_{a}$,などと引張強度 の間にはかなり明確な関係がみられたが，特に $\mathrm{f}_{a}$ と 引張強度の間には Fig. 7 に示したよらな単純な関係 があった。筆者らは乾留後に炭化して残留する量の多 い瀝青物ほど引張強度に寄与すると予想してや熱天科 による加熱残查量と引張強度との関係に最も注目して いた。しかしこの関係は Fig.7によく類似していた が直線性が劣っていた。特よらく，熱天科による乾留 条件と引張試験用の試料の乾留条件とが一致しないた めであろら。

Fig. 7 から歷青物の配合重量が一定の場合には歴青 物の種類にかかわらず引張強度と $\mathrm{f}_{a}$ はほぼ比例関係 


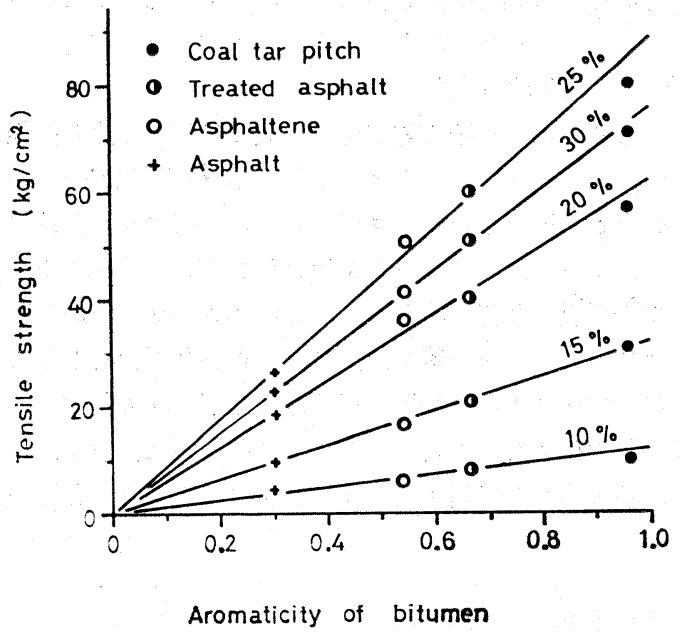

Fig. 7 Effect of bitumen aromaticity on the tensile strength

にあることが示された。したがって，峁る歴青物の $\mathrm{f}_{a}$ が求まれば瀝青物の種類を問わず引張強度が求ま ることになる。すなわち， $\mathrm{f}_{a}$ は乾留後の瀝青物によ る引張強度を評価する有効な指標となり得る。 $\mathrm{f}_{a}$ は 単位量の瀝青物中の総炭素数に占める芳香族炭素数の 割合を表わするのであるから， $\mathrm{f}_{a}$ と引張強度の間に 比例関係があることは, 瀝青物中の芳香族構造が不活 性物粒子間の結合に有効であることを意味している。

\subsection{2 瀝青物に上る最適不活性物配合量}

Fig. 6 によると瀝青物の種類によらず最適不活性物 配合量はほぼ 25〜28wt.\% で一定している。最大引 張強度は最も高い石炭ピッチで約 $80 \mathrm{~kg} / \mathrm{cm}^{2}$ でめり 石炭類に比較すると（Fig. 3 参照）かなり低い值であ り夕特炭なみである。夕特炭は石炭類の中では引張強 度は低い方であるが，不活性物配合性は Fig.1からも 明らかなように石炭としては著しく高く，歷青物に近 い。したがって，石炭ピッチが成型コークス用のバイ ンダーとして使用可能であるならば，夕特炭のような 不活性物配合性のよい高流動性炭もバインダーとして 使用可能と考兄られる。

歴青物の種類によらず最適不活性物配合量がほぼ一 定している理由として次のように予想している。200 メッシュより細かく粉砝したコークスブリーズの粒子 がほぼ均一な球状であるとすると, 最密充垻して子理 論上 $26 \mathrm{vol} . \%$ の空陌が生ずる。藶青物はこの空隙を 埋めつくすまでは添加量が多くなるほど粒子間結合力

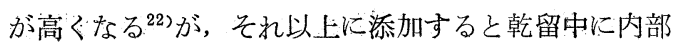

から発生するガスの逃散抵抗が增加し膨張する22)23)た め粒子間結合力は低下する。歴青度はその比重が 1.1 ～1. 3 程度であることを考慮すると 25 28wt. \% の 添加量は $20 \sim 25 \mathrm{vol} . \%$ に相当し，コークスブリーズ の粒子間隙体積とほぼ対応して和り, 引張強度が最大 飞達したものと予想される。しかし, 現在のところ詳 細は不明である。

\section{3 を め}

藶青物に関する実駼結果特よび考察をまとめると次 のと招りである。

（1）歴青物による引張強度は瀝青物の重質化の程 度と密接に関連して特り, 特に $\mathrm{f}_{a}$ と引張強度の間に は正比例関係が見られた。すなわち, 瀝青物中の芳香 族構造部分が不活性物粒子間の結合に寄与しているこ とが示された。

(2) 瀝青物は種類のいかんによらず 25〜28wt. \%配合した時に引張強度が最大に達した。これは不活 性物粒子間隙を埋め尽すのに必要な瀝青物の量とも考 えられるが詳細は不明である。

\section{4. 総 括}

成型コークス製造の際の配合組成や原料炭の役割, 橬青物バインダーの選定なぞに関する知見を得ること を目的として石炭や瀝青物による不活性物粒子間結合 力を I. T. T. 法によって測定した。その結果, 石炭や 嶷青物の特性と不活性物粒子間結合効果との関係を明

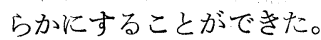

石炭についてみると，不活性物粒子間結合効果は活 性質の夕イプに依存し, 活性質の夕イプによって最適 不活性物配合量や最大引張強度が決まる。特に最適不 活性物配合量は重量割合で配合する限り, 不活性物の 種類によらず活性質のタイプで決まるので，活性の質 量/不活性質の量を重量単位で表示した O. I. R. 曲線 を作成して括将ば原料炭の配合組成の適否の判定が容 易になる。

瀝青物についてみると，不活性物粒子間結合効果は 重質化の程度に依存し, 特に $\mathrm{f}_{a}$ の大きさと引張強度 の間に正比例関係が存在する。しかし，石炭の場合々 異なり最適不活性物配合量は瀝青物の種類によらず一 定している。このため擵青物バインダーを引張強度の 大きさの点から選択することは容易にできる。しか し, 歷青物バインダーは乾留後のブリケットの強度の みならず生ブリケットの強度維持も目的としているの で, 単に $\mathrm{f}_{a}$ が高いだけでは充分でなく, ある程度の 粘弾性子要求される ${ }^{24)}$ 27) ととに留意する必要がある。 
文献

1）宮川, 藤嶋, 燃協誌, 983 (1975)

2) W. Reerink, J. Inst. Fuel, 285, 290 (1970)

3) W. Peter, Glückauf, 103, 1273 (1967)

4) I. Stefanescu, Stahl u. Eisen, 88, 342 (1968)

5) D. W. van Krevelen, H. N. M. Dormans, F. J. Huntjens, Fuel, 35, 462 (1956)

6) J. K. Brown, I. G. C. Dryden, D. H. Dunevein, W. K. Joy, K. S. Pankhurst, J. Inst. Fuel, 31, 259 (1958)

7) D. Fitzgerald, D. W. van Krevelen, Fuel, 38, 17 (1959)

8) C. Kröger, A. Pohl, Brennstoff-Chem., 38, 102 (1957)

9) A.P. Oele, ibid., 33, 231 (1952)

10) M. Kugo, J. Chem. Soc. Japan, Ind. Chem. Sect., 54, 628 (1951)

11) A. F. Byer, J. Lahouste, R. Malzieu, Rev. ind. minerale, 39, 232 (1957)

12) C. Arnu, Congr. assoc. tech. gaz, Paris, 1959, 281

13) P. L. Waters, W. R. Hesp, J. Inst, Fuel, 34, 323 (1961)

14) C. Georgiadis, G. Gaillard, Chaleur \& ind.,
32, 247 (1956)

15) I. L. Ammosov et al., Koks i Khimiya, 12, 9 (1957)

16) N. Schapiro, R. J. Gray, J. Inst. Fuel, 37, 234 (1964)

17) L. G. Benedict, R. R. Thompson, R.O. Wenger, Blast Furnace and steel Plant, 64, 683(1968)

18) T. K. Gnosh, Econ Geol., 64, 683 (1969)

19) H. R. Brown, G. H. Taylor, A.C. Cook, Fuel, 43, 43 (1964)

20) N. Kaye, C. O. M. A. Year-book, pp193 (1967)

21) A.C.Cook, G. E. Edwards, Fuel, 50, 41(1971)

22) D. W. Gillmore, C. C. Wright, C. R. Kinney, J. Inst. Fuel, 32, 50 (1959)

23) A. D. Dainton, W. G. Kaye, ibid., 32, 571 (1959)

24) H. Broche, H. Nedelmann, Glückauf, 69, 233, 257 (1933)

25) W. Demann, Brenstoff-Chem., 14, 121 (1933)

26) E. Swartzmann, Wyoming Univ., Natl. Resources Inst., Inform. Circ., No. 3, pp70 (1949)

27) L. J. Wood, Coal Tar Research Assoc., Rept. No. 0140 (1955) pp28

28）宮川, 藤嶋, 武上, 鈴木, 燃協誌, 53, 99(1974)

The Tensile Strength of Industrial Cokes (2) The Binder Efficiency of Bituminous Coals and Bitumens

\author{
by Ichiro Fujishima and Tsugio Miyagawa
}

(Kawasaki Steel Corporation)

SYNOPSIS :-In order to exmine the characteristics of bituminous coals or bitumens as binder these materials were carbonized with coke breeze or anthracite fines. The tensile strength of these cokes was measured using indirect tensile test.

A study of the results has led to the conclusion that there exists a definite correlation between the tensile strength and the binder properties. The efficiency of binder coal such as maximum tensile strength and optimum inert ratio is determined by the type of vitrinite. The aromaticity of bitumens is directly proportional to the tensile strength of coke caronized from bitumen blended inerts. But bitumens examined in this paper have the same value of optimum inert ratio. 